\title{
琵琶湖の鴨川河口部と近江白浜の湖浜変形 \\ LAKESHORE CHANGES AROUND KAMO RIVER MOUTH AND OHMI-SHIRAHAMA REGION IN LAKE BIWA
}

\author{
山崎彰吾 1 •引山 誠 1 ・宇多高明 2 ・星上幸良 3 ・ \\ 小澤宏樹3 ・清水達也4 ・ 野志保仁 5 \\ Shogo YAMAZAKI, Makoto HIKIYAMA, Takaaki UDA, Yukiyoshi HOSHIGAMI, \\ Hiroki OZAWA, Tatsuya SHIMIZU and Yasuhito NOSHI \\ 1滋賀県高島土木事務所（干520-1621 滋賀県高島市今津町今津1758） \\ 2正会員 工博（財）土木研究センター常務理事なぎさ総合研究室長兼 \\ 日本大学客員教授理工学部海洋建築工学科（†110-0016 東京都台東区台東1-6-4タカラビル） \\ 3正会員 博（工） 国際航業株式会社河川環境部（†183-0057 東京都府中市春日町1-24-1） \\ 4正会員 修（工）（有）アイコムネット環境コンサルティング部 \\ （テ135-0064 東京都江東区青海2-7-4-627） \\ 5 正会員 博（工）（有）アイコムネット環境コンサルティング部 \\ （†135-0064 東京都江東区青海2-7-4-627）
}

\begin{abstract}
Lakeshore changes around the Kamo River mouth and Ohmi-shirahama Region in Lake Biwa were investigated. River improvement was carried out in the Kamo River as a countermeasure against floods by excavating the riverbed to widen the river channel. After the river improvement, sand discharge from the river was significantly reduced and shoreline recession occurred around the river mouth. Such situation was investigated by comparison of past aerial photographs. Longshore sand transport was also estimated from the shoreline changes.
\end{abstract}

Key Words : Lakeshore changes, Lake Biwa, river improvement, sand discharge, longshore sand transport

\section{1.はじめに}

琵琶湖では流入河川の治水対策の一環として河道 掘削や新放水路の開削が各地で行われてきた。この 結果，河川改修の行われた河川では琵琶湖への流入 土砂が激減し，河口からの土砂流入を前提として形 成されてきた湖浜において沿岸漂砂とのバランスが 失われ，河口部を中心とする湖浜で著しい侵食が起 きている。例えば，琵琶湖（北湖）南部に流入する 野洲川河口では，河口付け替え工事に伴って旧野洲 川河口部で侵食が進んだ1)。同じく琵琶湖東岸に位 置する旧野洲川河口の東，約 $5 \mathrm{~km}$ に流入する日野川 河口でも河口部掘削が要因となって河口デルタ縮小 が起きており，播磨ら ${ }^{2)}$ は1960年代以降の日野川河 口域湖岸の変遷を空中写真の比較により明らかにし た。一方，安東・倉茂 ${ }^{3)}$ は，琵琶湖東岸に流入する 犬上川においても1992-1993年に洪水制御の目的で 10 万 $\mathrm{m}^{3}$ を超える土砂が河口部で掘削され，これに よって河口デルタの大部分が消失するとともに，掘 削によって生じた凹地を埋積して平衡状態に達しよ うとする地形変化が起きたことを明らかにした。ま
た波浪の現地観測と数值計算により河口部の地形変 化過程について考察した。琵琶湖中央部, 安量川河 ロデルタの一部をなす鴨川河口部においても, 旧野 洲川，日野川および犬上川河口と同様な原因により 侵食が進んできており，現在隣接の近江白浜での湖 浜復元が課題となっている. 湖浜の侵食に対し, 杉 村ら ${ }^{4)}$ は，播磨ら ${ }^{2)}$ が明らかにした日野川河口デル タの縮小に伴う右岸側海浜の侵食対策として養浜実 験を行い, 突堤群による養浜汀線の安定化策を示し た. 本研究は, 同様な主旨より鴨川河口部の変遷を 調べ，また湖浜縦断形の測定などをもとに湖浜変形 の定量データを取得し，下手側に位置する近江白浜 の湖浜復元方策検討のための基本資料を得ることを 目的とする.

\section{2. 調査対象地区の特徵}

研究対象の鴨川は，比良山系武奈厅岳の八淵ノ滝 に源を発し, 琵琶湖へ注ぐ流域面積 $207.7 \mathrm{~km}^{2}$, 流路 延長 $33 \mathrm{~km}$ の二級河川である。安量川は比良山地から 


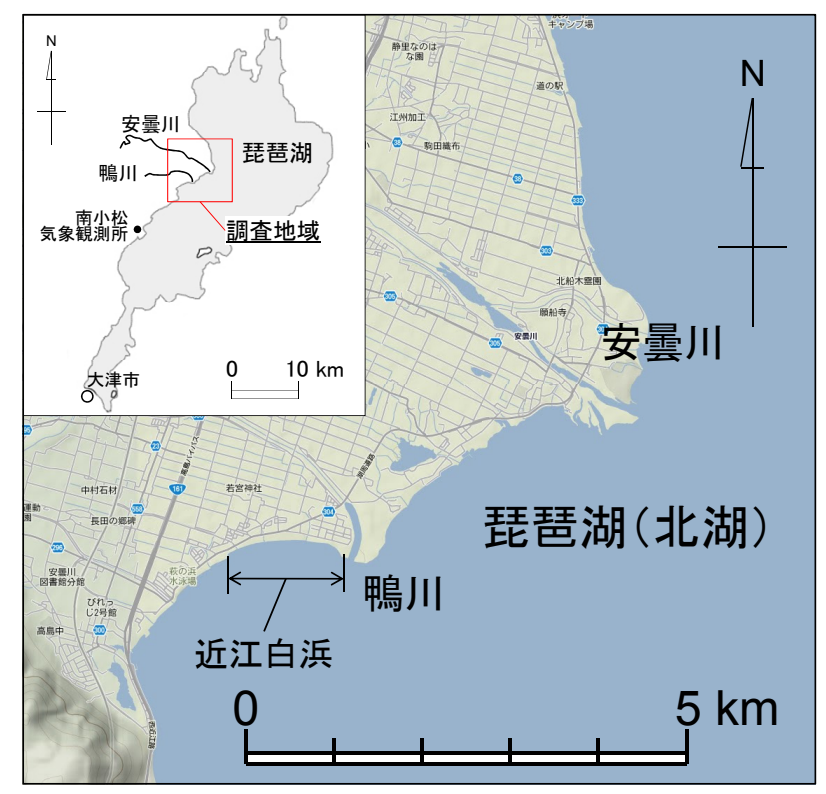

図-1 鴨川の位置

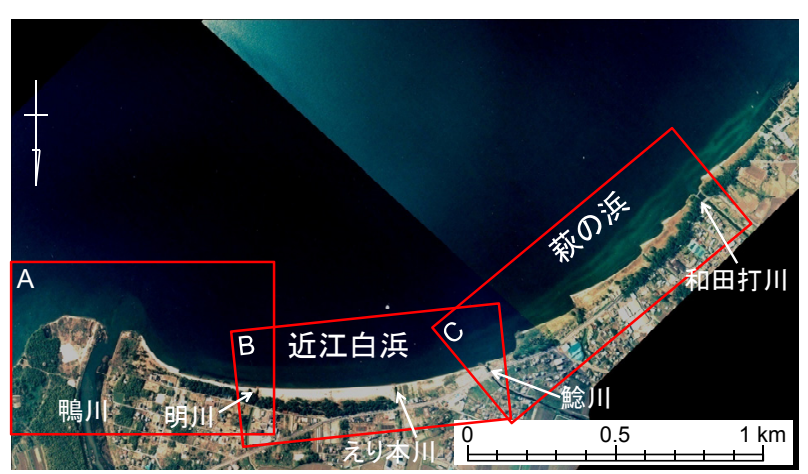

図-2 鴨川河口とその西側に位置する近江白浜および萩の 浜の空中写真 (2010 年撮影)

大量の土砂を輸送してきたため河口部に規模の大き な河口デルタを発達させている，現況の鴨川は，図 -1に示すように安曇川河口デルタの南端部において 南向きに流入している. 鴨川河口の西側には長さ約 $1,400 \mathrm{~m}$ 砂浜（近江白浜）が広がるが，この海浜の 東部で侵食が進んできており, 有効な手立てが必要 とされている.

図-2は，鴨川河口とその西側に位置する近江白浜， および萩の浜の空中写真（2010年撮影）を示す。現 況の鴨川河口は南南西へ向き, 河道幅約 $60 \mathrm{~m}$ で緩や かなカーブを描いて琵琶湖に流入している。河口部 汀線は琵琶湖に大きく突出しているが，河口に規模 の大きな砂州は存在せず, 河口両岸では護岸が露出 している.これは河川改修の一環として河口掘削が 行われたことによる. 河口の西側には近江白浜の砂 浜が，またその南西側には萩の浜が延びる。萩の浜 の湖浜は5基の突堤群で区切られており, 汀線が階 段状となっている。 これらの突堤群では突堤の南西 側の汀線が北東側より張り出していることから，萩 の浜では近江白浜方面への沿岸漂砂が発達する条件 にあることが見てとれる。一方，東端の鴨川河口部 汀線も琵琶湖に大きく突出していることから, 河川 流出土砂量が潤沢であった時期には河口から近江白 (a) 風向頻度

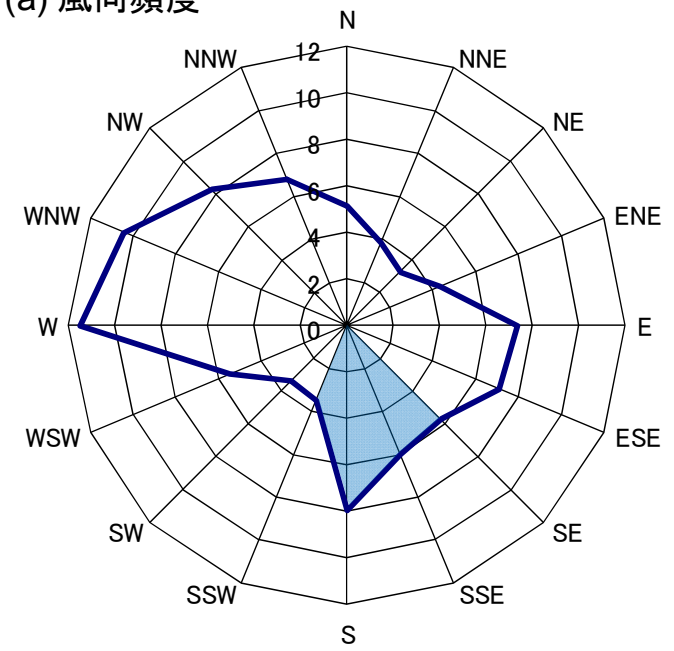

(b) SSW SE方向の波エネルギー比

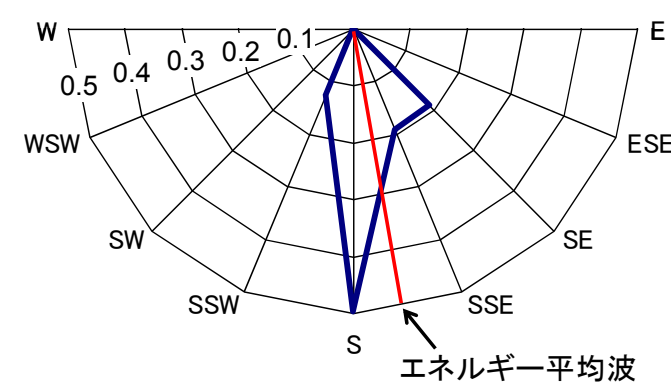

波向: $S 9.7^{\circ} \mathrm{E}$ 波高: $0.66 \mathrm{~m}$ 周期: $2.8 \mathrm{~s}$

図-3 南小松気象観測所における風配図

浜方向への砂供給があったと考えられる.これらの ことから, 近江白浜はその両端から砂供給を受けて 発達してきたと考えられる.

近江白浜の南東 $10.6 \mathrm{~km}$ に位置する南小松気象観測 所（図-1参照）における2005年1月から2010年3月ま での観測データをもとに作成した風配図を図-3(a) に示す. 南小松地先では冬季に発達するWまたは WNW方向の風が卓越し, そのほがおよびS方向に もピークがある。しかし近江白浜では，東側は鴨川 河口によって塞がれ，また西側は琵琶湖西岸が延び ているため風波の作用範囲はSSW〜 SE間となる. この間ではSが最も卓越している。図-3(b)には $\mathrm{SSW} \sim \mathrm{SW}$ 方向の波エネルギー比の分布と, エネル ギー平均波の入射方向を示寸が，卓越波向はS $9.7^{\circ} \mathrm{E}$, 波高は $0.66 \mathrm{~m}$ ，周期は $2.8 \mathrm{~s}$ である. 図-2に示した近 江白浜の空中写真と考え合わせると, 卓越波浪によ り誘起された沿岸漂砂は近江白浜中央部への堆砂を 促す.

\section{3. 各地域の湖岸の経年的変化}

図-2に示した調查対象区域は，その特徽から見て 鴨川河口域（A），近江白浜（B），および萩の浜

（C）に区分される．以下ではこれら小区域の1961, 1990，2010年における湖岸状況の変化を調べた. 


\section{（1）鴨川河口部}

図-4は鴨川河口部の変遷を示す。1961年には鴨川 の流路は河口部で乱れ, 河ロデルタは南西方向に発 達していた。 河口の最突出点を $\mathrm{P}$ とると, 当時の 河口デルタはデルタ外縁の点 $\mathrm{Q}, \mathrm{R}$ を結ぶ線上に載 り，PQ間では汀線勾配が急で，PR間ではなだらか にすり付く汀線形状であった. Q点の東側の突出し た汀線もまた鴨川からの流出土砂が堆積した結果円 弧状に湖内一と突出したものである。また1961年に は河口を含む東西両側の湖浜が連続的に繋がってい たことが注目される．このことから1961年当時鴨川 から土砂供給を潤沢に受けていたことが分かる.

1990年になると，1961年当時のPQ間に新たな直 線河道が掘削された。河道掘削に伴い土砂が除去さ れ川幅が広がって掃流力が減少したために, 新河口 での汀線の前進はあるものの, 湖岸への土砂供給量 が減少したと考えられる。 Q点以東では河道の乱流 によって直接湖岸に土砂が供給されていたが，新河 道の開削により土砂供給が途絶え，また新河口方面 からの土砂供給も減少したため, 汀線の著しい後退 が始まった。 さらに1961年には大きく突出していた $\mathrm{P}$ 点以西でも土砂供給量が大きく減少したため汀線 の後退が起きた。一方, 1961年当時の右岸砂州の一 部は樹林帯に変わり, 直線QRを超えて南側最大 $35 \mathrm{~m}$ まで植生帯が発達した。

2010年では，1990年当時と河道形状には変化がな いが, 河口部の掘削が行われ, 河口両岸の砂浜は消 失した。鴨川からの土砂供給が途絶えたために, 河 口左岸では汀線が著しく後退した。右岸側では近江 白浜との接点R以西で1961年当時より汀線の後退が 起きた。なお点Rには捨石突堤が設置され，この点 より河口側では㗂養浜が行われている。 突堤建設に

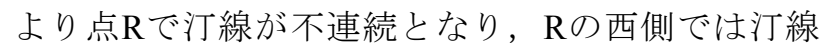
が約10m後退した。

\section{(2) 近江白浜}

図-5は明川から鯰川付近（区域B）の湖岸変遷を 示寸.1961年の近江白浜は緩やかに湾曲した砂浜で あり, 最も砂浜幅が広い場所では約 $40 \mathrm{~m} の$ 湖浜が あった. 1990年には近江白浜の大部分で汀線が前進 し，とくにえり本川河口左岸付近では最大 $15 \mathrm{~m} の$ 汀 線前進が起きた。これと対照的に, 鯰川河口右岸で は汀線が $10 \mathrm{~m}$ 後退した。汀線前進量が明川河口から えり本川方面へと増加する一方, 鯰川河口右岸では 後退していた汀線が河口左岸では前進傾向へと変化 することから, 近江白浜は両側からの沿岸漂砂が集 まる区域で, 漂砂の会合点はほぼえり本川河口左岸 付近にあることが分かる.2010年では1990年と大き な変化は起きていないが, 鴨川河口方面から始まっ た侵食が明川にまで到達して汀線後退が始まった。 しかし1961年から1990年の間に汀線後退が著しかっ た鯰川河口方面では汀線変化はほぼ終息した。
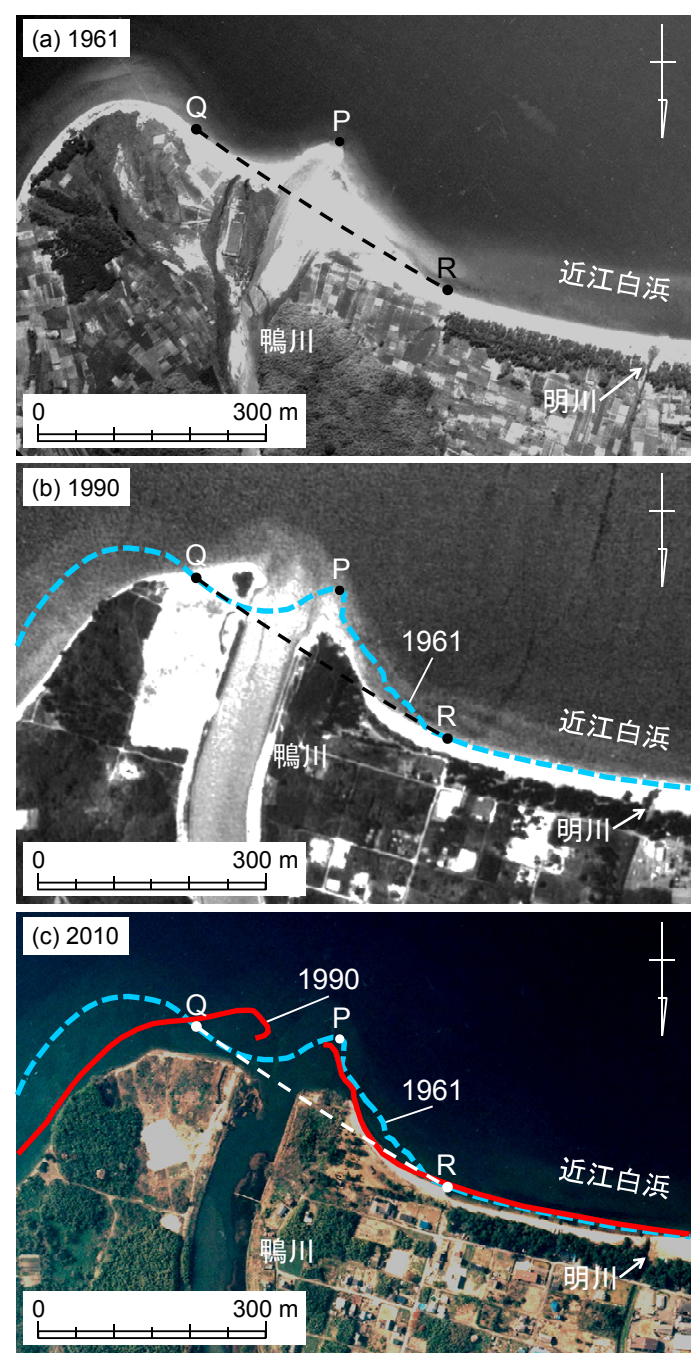

図-4 鴨川河口部の変遷
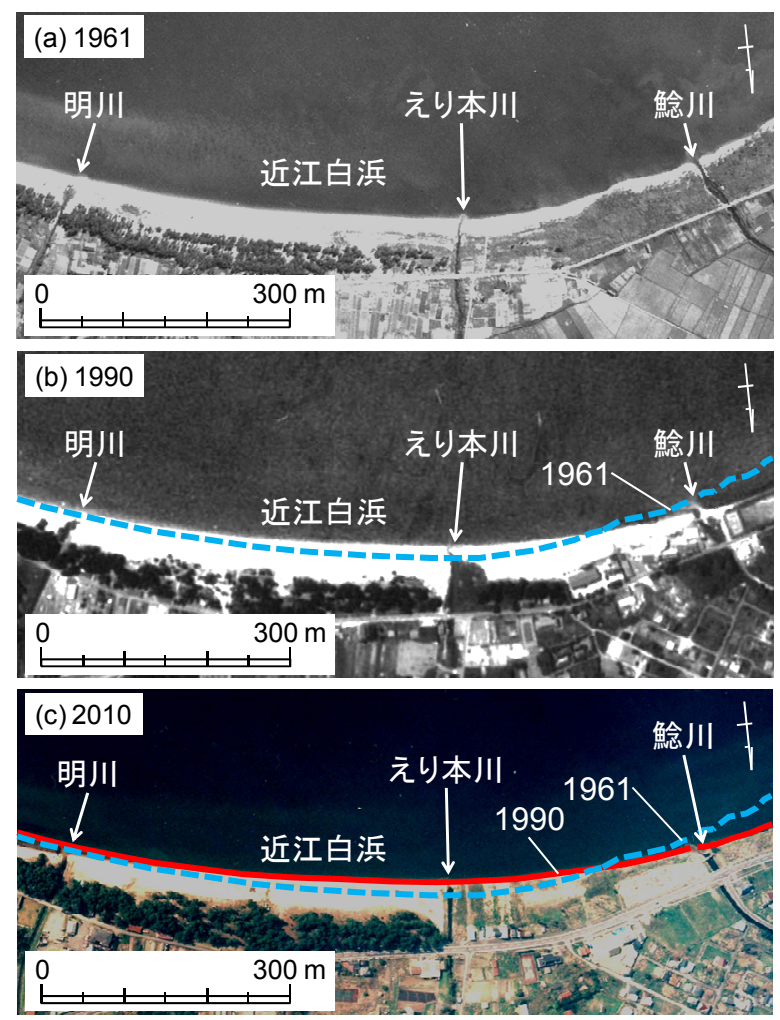

図-5 明川から鯰川付近（区域 B）の湖岸変遷 


\section{（3）萩の浜}

図-6は萩の浜（区域C）の湖岸変遷を示す。1961 年当時萩の浜では砂浜が連続しており，湖岸では沿 岸漂砂の連続性が保たれていた。また湖浜沖には3 列の沿岸砂州の発達が見られた。1990年には鯰川河 口右岸の湖岸で掘削が行われ，約 $2,500 \mathrm{~m}^{2}$ の湖浜が 消失した。また鯰川河口の西 $350 \mathrm{~m}$ には突堤が伸ばさ れた。最も大きな変化が現われたのは萩の浜西端部 である。そこでは1961年には和田打川の河ロデルタ が突出していたが，この両側の湖浜は侵食により消 失した。また萩の浜中央部でも全体的な汀線後退が 起きた。2010年までには萩の浜では連続的に繋がっ た砂浜は消失し，5箇所に設置された突堤の西側に のみ砂浜が残されるという静的安定な湖浜の姿へと 変化した。1961年には沿岸漂砂が連続的に流れる動 的平衡状態にあったが，2010年には沿岸漂砂が突堤 位置で切断された静的平衡状態に近づいたことが分 かる.

\section{4. 汀線変化}

人工的改変が行われる前の1961年を基準とした汀 線変化を算出した（図-7）。その際，汀線変化を理 解しやすくするため1995年までと2010年までの汀線 変化に分けて整理した。図-7(a)によれば，鴨川河 口左岸のQ点以東では河口デルタの縮小に伴って汀 線が後退した。河口右岸でも, 鴨川からの供給土砂 量の減少に伴い汀線の後退が起きたが，明川河口以 西では堆積傾向を示し, 明川河口の西480m（鯰川河 口の東 $250 \mathrm{~m} ）$ の点 $\mathrm{M} て ゙$ 汀線は最大の前進量をとる. 一方，萩の浜では4箇所に設置された突堤により階 段状の汀線が形成され，とくに東端の突堤G1では 突堤建設後その西側では $16 \mathrm{~m}$ 汀線が前進する一方, 東側では38mの後退が起きた．図-7 (b) に示す2001〜 2010年の変化では, 各地域の汀線変動量が小さくな り，捨石突堤〜明川など一部区間を残して全体とし て河川改修に伴う土砂供給量の減少による湖浜地形 変化が終息状態に近づいたことが分かる.

\section{5. 波向の沿岸方向分布}

図-8に示す2010年の空中写真においては，汀線が ほぼ静的安定状態にあることから，5地点において 波向角の推定が可能である.これらは鴨川河口左岸 の地点(1), えり本川河口近傍の沿岸漂砂の会合点(2) 萩の浜の突堤上手側の地点(3)(4)(5)であり，いずれの 地点でも汀線への法線を定めれば波の入射方向が得 られる。なお地点(1)では砂州上に繁茂した植生帯が 直線状に切られていることからこの直線は波向とほ ぼ直角になっていると考えられる。図-9はこれら5 地点におけるSから反時計回りを正として測った波 向の沿岸方向分布を示す. 波向はほぼ線形的に変化
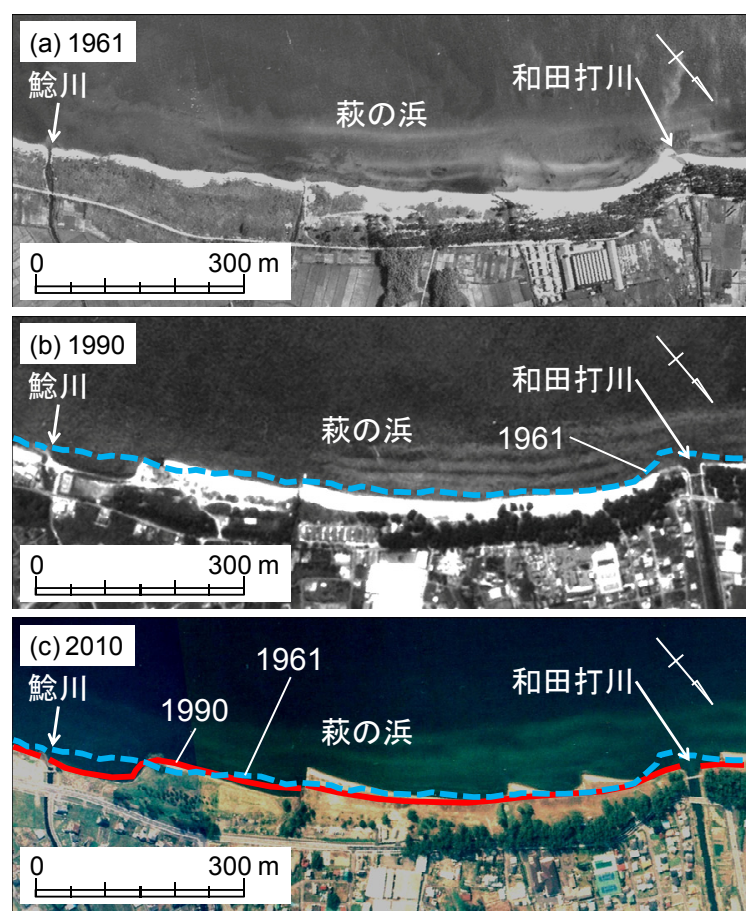

図-6 萩の浜（区域 C）の湖岸変遷

(a) $1975,1990,1995$ 年までの汀線変化

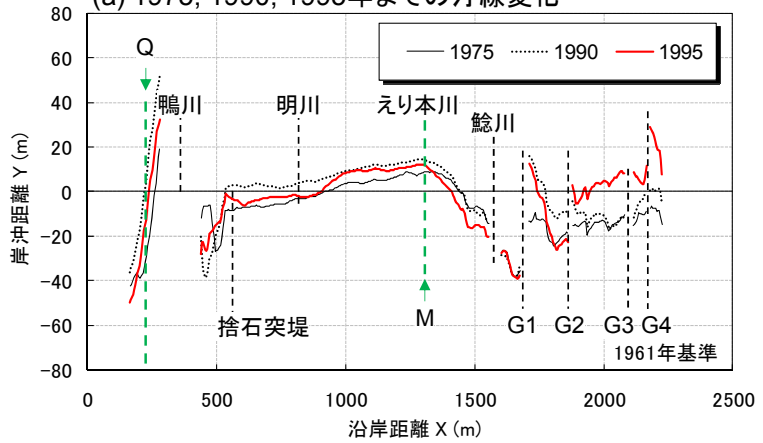

(b) $2001,2003,2010$ 年までの汀線変化

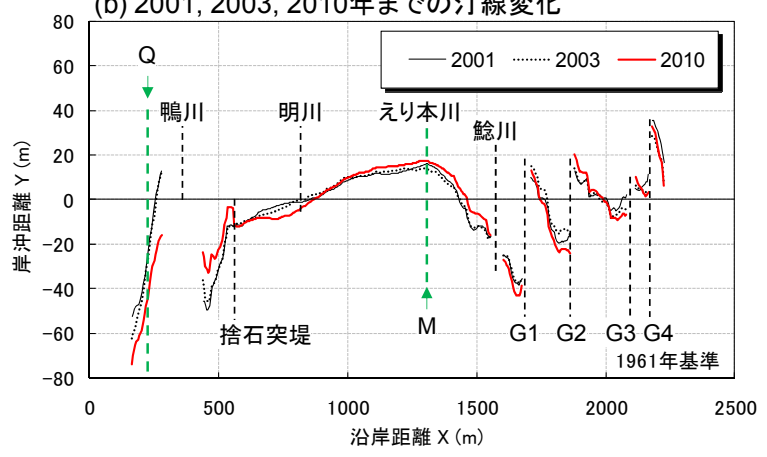

図-7 1961 年を基準とした汀線変化

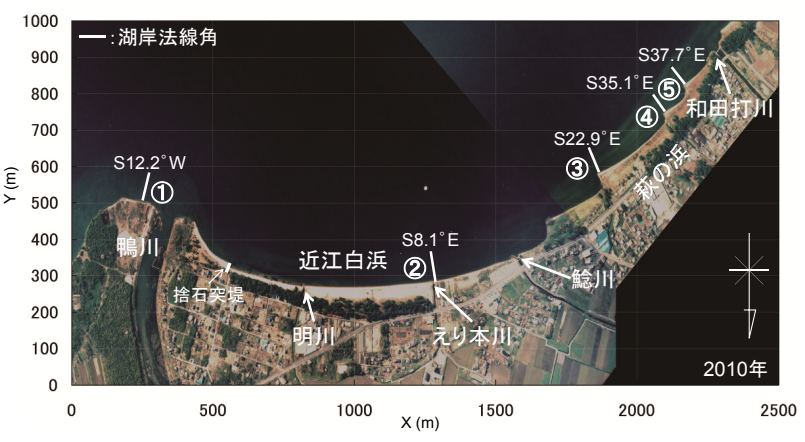

図-8 2010 年の空中写真 


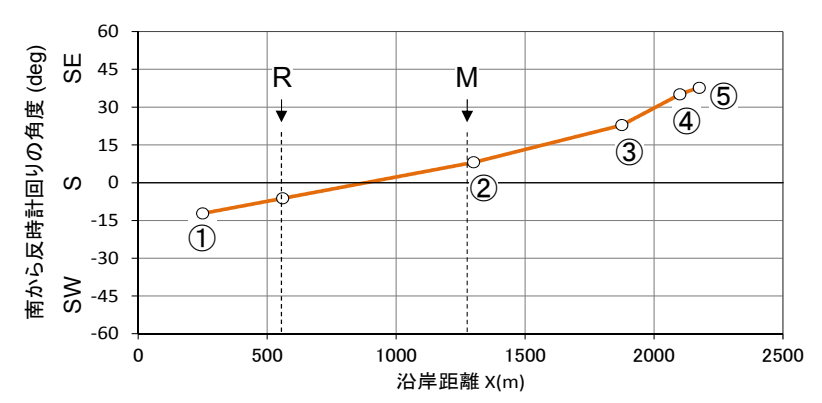

図-9 波向の沿岸方向分布

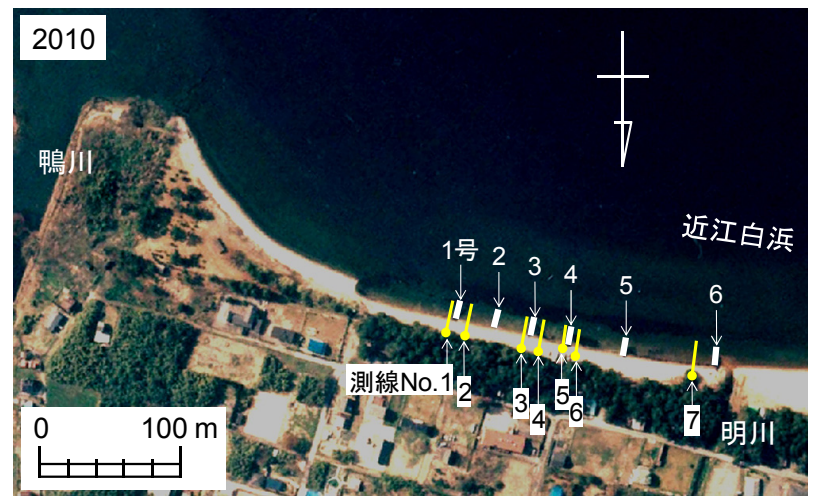

図-10 試験突堤の配置

し，捨石突堤（R）と沿岸漂砂の会合点（M）まで の間ではS6. $2^{\circ} \mathrm{W} か ら \mathrm{~S} 8.1^{\circ} \mathrm{E}$ の間で変化しているこ とが分かる.

\section{6. 縦断形変化と漂砂の移動高}

近江白浜東部の捨石突堤（R）と明川間の $270 \mathrm{~m}$ 区 間では6基の土囊製試験突堤が設置され，それらの 漂砂制御効果が調べられている。試験突堤の配置は 図-10のようであり，突堤長は約 $7 \mathrm{~m}$ ，突堤間隔は東 側では $23 \mathrm{~m}$ と狭く，西側では65mと広い。2010年7月9 日，これらの試験突堤を挟む7測線に沿って縦断形 を測定した。図-11，12，13にはNo.1，2，No.3，4 およびNo.5，6の縦断形の重㸚合わせ図を示す。な お, 琵琶湖の平均水面B.S.L.0mはT.P.84. 371mに等し い。これらによると, 突堤の東側に位置する測線で はいずれも砂の堆積により鉛直上方に凸な縦断形と なり, 両断面には差異が認められる。これらの差異 は突堤による沿岸漂砂阻止に起因寸ると考えられる ことから,これらの縦断形より断面積変化量 $(\Delta \mathrm{A})$ と汀線変化量 $(\Delta \mathrm{y})$ を求めた。また全7断 面は図-14に示すように+1mから陸側と， $-0.6 \mathrm{~m} よ り$ 沖合の縦断形が重なりを示し，この間で波による地 形変化が起きていることを示唆する．このことから 縦断形変化の時間一空間の入れ替えの考え方 ${ }^{5}$ に基 づいて断面形の場所的変化を時間的変化に置き換え， 凸な縦断形（No.1，3，5，7） と凹んだ縦断形

（No.2，4，6）の組み合わせで断面積変化と見かけ の汀線変化を算出し，それらの相関を調べれば移動

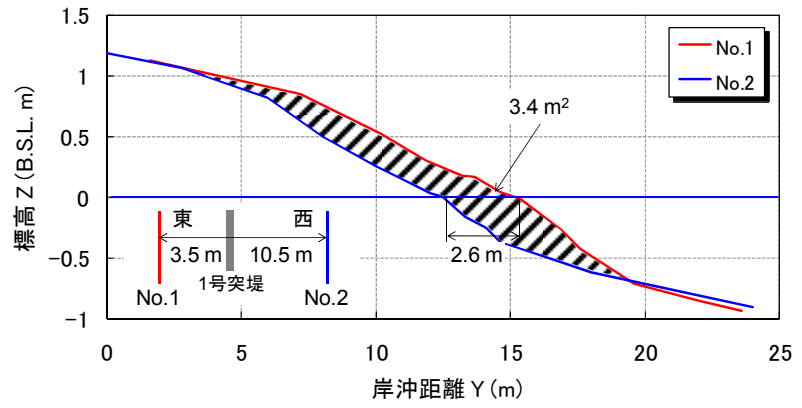

図-11 No.1，2 の縦断形の重ね合わせ図

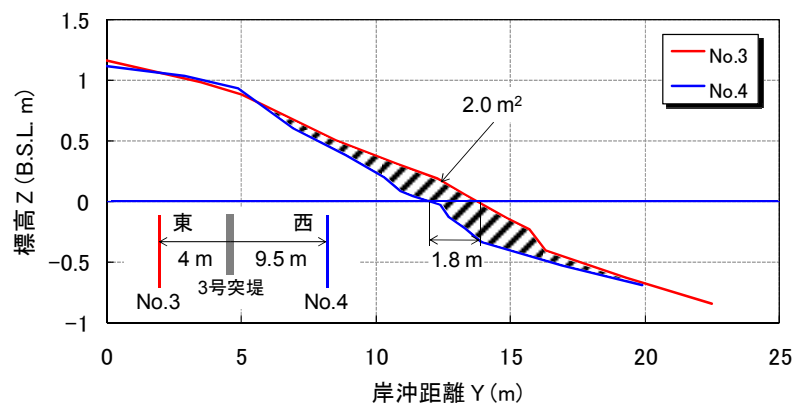

図-12 No.3，4の縦断形の重ね合わせ図

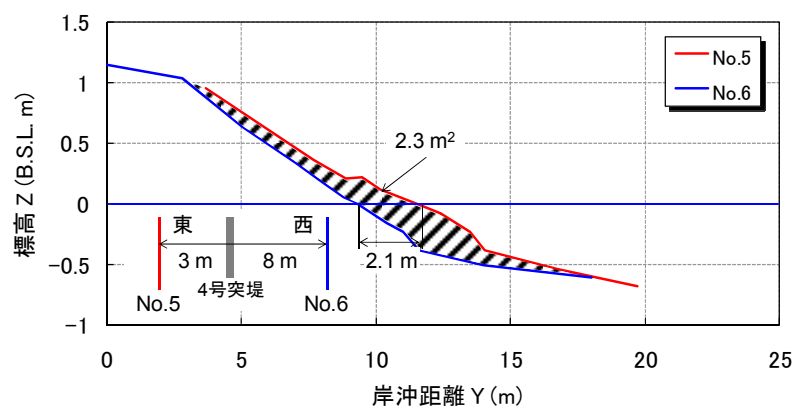

図-13 No.5，6 の縦断形の重祆合わせ図

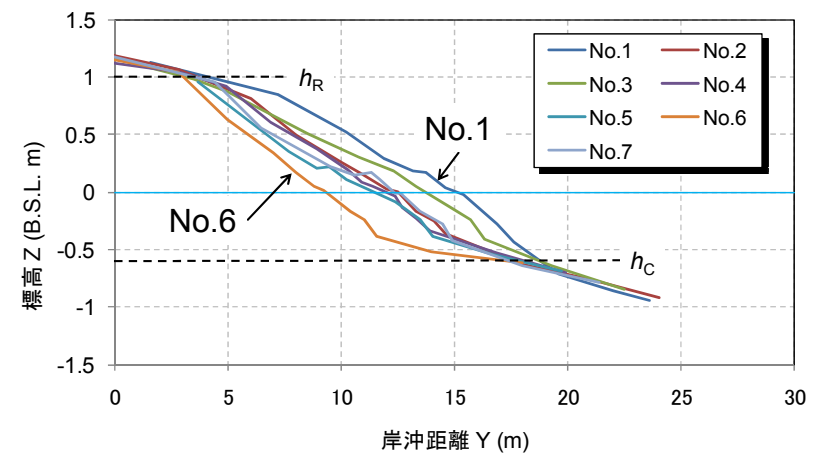

図-14 全 7 断面の重ね合わせ図

高の推定ができる．図-15は以上の検討結果を示す が， $\Delta \mathrm{A}$ と $\Delta \mathrm{y}$ の比例係数は漂砂の移動高 $\mathrm{h}$ をえる ので, $\mathrm{h} は 1.2 \mathrm{~m}$ とる.

杉村ら ${ }^{4)}$ は, 日野川河口右岸での試験養浜におい て2005年3月の縦断形を基準として2007年 $2 ， 4 ， 10$ 月までの $\Delta \mathrm{A} と \Delta \mathrm{y}$ 求め, 両者の相関より漂砂の移 動高を $1.17 \mathrm{~m}$ と算定した。これを参照すると鴨川河 口での漂砂の移動高は, 日野川河口での值とほぼ一 致する. 


\section{7. 沿岸漂砂量分布の推定}

図-7の汀線変化に示したように，明川と鯰川間の 点 $\mathrm{M}$ では汀線が経年的に前進し，同時に汀線の最大 前進量が見られることから, 点 $\mathrm{M}$ は鴨川から近江白 浜への西向き沿岸漂砂と萩の浜からの東向き沿岸漂 砂のほぼ会合点を与える。沿岸漂砂の会合点ならぼ そこでの沿岸漂砂量は 0 となるので，M点を中心に 汀線変動量を沿岸方向に積分し，それに漂砂の移動 高を乗じることにより沿岸漂砂量分布が定められる 5)。また鴨川からの土砂流出条件は1995年頃から大 きく変化したことから，2001年までと2010年までの 2時期に分けて沿岸漂砂量を算出した.

図-16 (a) は2001年までの沿岸漂砂量分布を示寸. 鴨川河口と漂砂の会合点 $\mathrm{M}$ までの区域での最大沿岸 漂砂量は1975年にはX=920m付近にあり $33 \mathrm{~m}^{3} / \mathrm{yr}$ で あったが，鴨川河口で新河道が造られた1990年には、 河道が広げられたことにより河口隣接部で局所的に $45 \mathrm{~m}^{3} / \mathrm{yr}$ と漂砂量が著しく増大した。しかし1995年 までには流出土砂量の減少に伴い沿岸漂砂量も減少 し， X=900mで $25 \mathrm{~m}^{3} / \mathrm{yr}$ となった。これに対して萩の 浜では突堤群が建設されたことにより，各突堤で沿 岸漂砂量が0で西側に増加するという階段状分布を 持つ沿岸漂砂量分布となった。同じく図-16(b) は 2003年以降における沿岸漂砂量分布を示す。流出土 砂量の減少が起きてから時間が経過したため沿岸漂 砂量の絶対值が減少している.

\section{8. あとがき}

本研究によれば, 琵琶湖（北湖）に流入する鴨川 における河川改修によって流下土砂量が急減し，こ れによって河口部の汀線後退が，さらに隣接の近江 白浜の侵食が起きたことが分かった。 今後の河川改 修においては，このような河口周辺海岸への影響も 十分考慮して進めること，また影響が予測される場 合には，突堤などを用いた湖浜安定化が必要と考え られる。

\section{参考文献}

1) 宇多高明, 吉田隆昌, 西島照毅, 富士川洋一：琵琶湖 の野洲川放水路の開削に伴う旧河口周辺での湖浜変形, 地形, Vol. 16, pp. 157-175, 1995.

2) 播磨光一，杉村重憲，宇多高明，中辻崇浩：琵琶湖に 流入する日野川河口域の地形変化とその要因, 海洋開 発論文集, 第 22 巻, pp. 421-426, 2006.

3) 安東新吾, 倉茂好匡 : 滋賀県犬上川河口部の掘削凹地 における地形の形成過程，地形，Vol.28，pp. 143-183, 2007.

4) 杉村重憲, 中辻崇浩，宇多高明：琵琶湖における試験

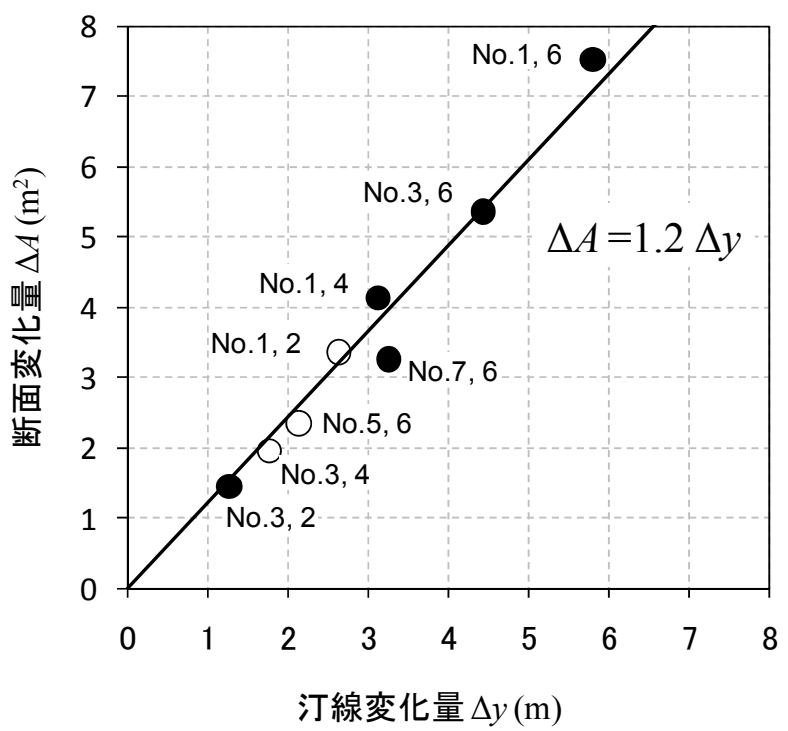

図-15 $\Delta \mathrm{A}$ と $\Delta \mathrm{y}$ の相関

(a) 2001 年までの沿岸漂砂量

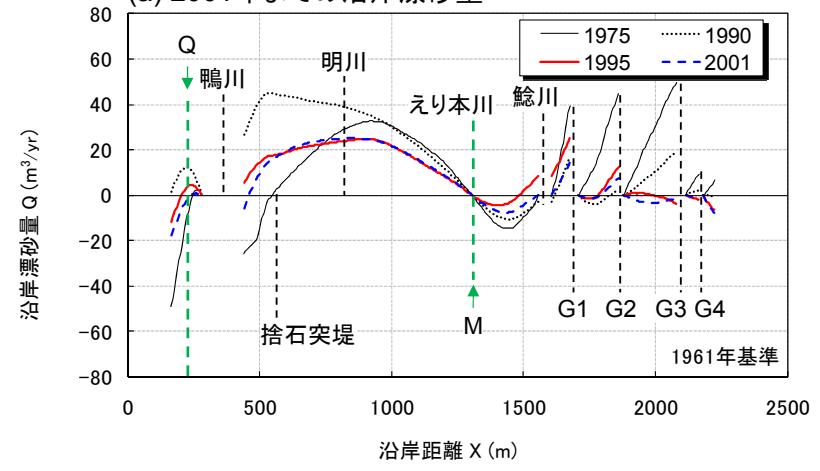

(b) 2010 年までの沿岸漂砂量

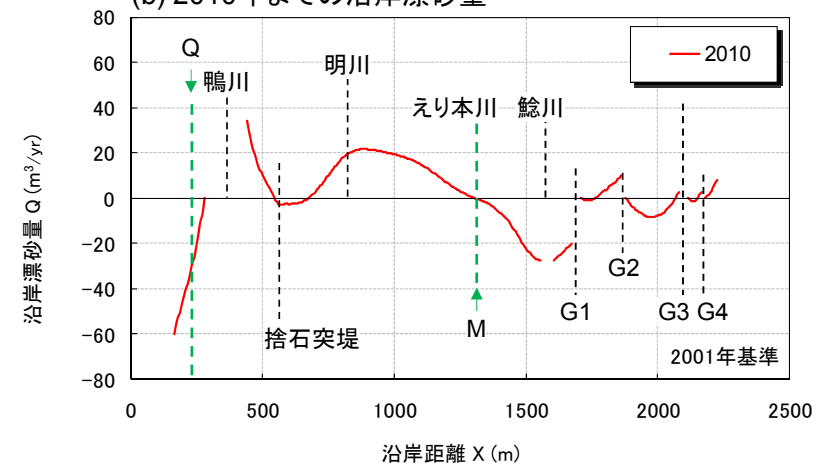

図-16 沿岸漂砂量分布

養浜のモニタリング調査, 水工学論文集, 第 53 巻, pp. 1435-1440, 2009.

5) 宇多高明 : 海岸侵食の実態と解決策, 山海堂, p. 304, 2005.

6) 宇多高明, 古池 鋼, 三波俊郎, 芹沢真澄 : 海食崖に 続く堆積性弧状海岸線の形成とその変形予測, 地形, Vol. 30, pp. 331-348, 2009. 